\title{
Design and Synthesis of Novel 2-Trichloromethyl-4- Substituted Quinazoline Derivatives as Anti-tubercular Agents
}

\author{
MANEESH KUMAR SRIVASTAV and S. M. SHANTAKUMAR* \\ Department of Pharmaceutical Chemistry, V. L. College of Pharmacy, Raichur-584103, \\ Karnataka, India \\ skmanish81@yahoo.com
}

Received 14 December 2012 / Accepted 13 January 2013

\begin{abstract}
In order to produce a new lead for anti-tubercular drug a series of novel 2-trichloromethyl quinazoline derivatives bearing substituted secondary amine group at the $4^{\text {th }}$ position were designed, synthesized and evaluated for their in vitro anti-tubercular activity against bacterial strain of M. tuberculosis H37Rv ATCC (American Type Culture Collection) by Alamar Blue assay method (MABA). The targeted molecules (4a-j) were synthesized from 4-chloro-2-(trichloromethyl) quinazoline and substituted secondary amine in dichloromethane using catalytic amount of KI, under reflux for 15-18 h. All the targeted compounds are new chemical entities and obtained in satisfactory yields and the structure of the synthesized compounds are in agreement with spectral data. Compound 4a and $\mathbf{4 f}$ exhibited potent anti-tubercular activity against bacterial strain of M. tuberculosis H37Rv, with MIC value $6.25 \mu \mathrm{G}$.
\end{abstract}

Keywords: Anti-tubercular activity, 2-Trichloromethyl quinazoline, Acetylation

\section{Introduction}

Tuberculosis is one of the oldest and most pervasive diseases in history ${ }^{1,2}$. According to alarming data from the World Health Organization (WHO), TB has spread to every corner of the globe. It is estimated that between 2002 and 2020, approximately 1000 million people will be newly infected, over 150 million people will develop diseases and 36 million will die due to TB if proper control measures are not established ${ }^{3}$. The directly observed treatment, short course (DOTS) strategy, constitutes the cornerstone of the current protocol for control of TB. However, the three key drugs, isoniazide, pyrazinamide and rifampicin, used in the regimen are potentially hepatotoxic and may lead to drug associated hepatitis ${ }^{4}$. Despite the undoubted success of DOTS strategy, the emergence of multi drug resistant strains, recurrently isolated from patient's sputum, darken the future. Furthermore, one of the main cases for the prevalence of TB is synergy with HIV epidemic, where $31 \%$ of new TB cases are attributable to HIV co-infection ${ }^{5}$. 
Many compounds are in clinical trials, it is astonishing that with this background, there have been no new drugs registered to treat TB in the last $45 \mathrm{yrs}$. This reflects the inherent difficulties in discovery and clinical testing of new agents and the lack of pharmaceutical industry research in this area $^{6}$. It was reported that quinazoline molecule were identified as a possible pharmacophores for anti-tubercular activity ${ }^{7-10}$. In the quest for biologically potent antitubercular agents, we have designed, synthesized and screened some 2-trichloromethyl-4substituted quinazoline derivatives to mimic those reported as potential anti-tubercular agents ${ }^{7-10}$.

\section{Experimental}

All the reagents and chemicals were procured from Sigma-Aldrich Company and used without further purification. Melting points were determined by using an open capillary tube method and are uncorrected. IR spectra $\left(\mathrm{V}_{\max }\right.$ in $\left.\mathrm{cm}^{-1}\right)$ were recorded on a Shimadzu FT-IR 8300 Spectrophotometer using $\mathrm{KBr}$ pellets technique. ${ }^{1} \mathrm{HNMR}$ Spectra were recorded using Bruker WM-400 spectrophotometer using $\mathrm{CDCl}_{3}$ as the solvent and tetramethylsilane (TMS) as the internal reference (Chemical Shifts in $\delta$, ppm). The purity of newly synthesized compounds was checked by TLC using silica gel G60 (Merck, Germany) plates in $n$-hexaneethyl acetate (9:1) solvent system and spots were visualized under UV light.

\section{2-Acetamidobenzoic acid (1)}

Anthranilic acid (1.37 g, $10.0 \mathrm{mmol})$ was taken in acetic anhydride $(4.08 \mathrm{~mL}, 40.0 \mathrm{mmol})$ and refluxed under anhydrous conditions for $4 \mathrm{~h}$. Excess of acetic anhydride was distilled off under reduced pressure and obtained solid was kept in petroleum ether for $1 \mathrm{~h}$, filtered and washed thoroughly with cold water. Dried and recrystallized to give compound $\mathbf{5}$ in yield 85\%; m.p 181-183 ${ }^{\circ} \mathrm{C}$ (Aq. EtOH); ${ }^{1} \mathrm{H}$ NMR $\left(\mathrm{CDCl}_{3}\right) \delta$ : 2.3 (s, $3 \mathrm{H}$ of $\left.\mathrm{CH}_{3}\right)$, 7.3-8.9 (m, $4 \mathrm{H}$ of $\mathrm{Ar}-\mathrm{H}), 10.8$ (s, 1H of $\mathrm{NH}), 12.8(\mathrm{~s}, 1 \mathrm{H}$ of $\mathrm{OH}$ of $-\mathrm{COOH})$. MS $(\mathrm{m} / \mathrm{z}): \mathrm{M}^{+1}=180$.

\section{2-Methylquinazolin-4(3H)-one (2)}

2-Acetamidobenzoic acid (1) $(1.79 \mathrm{~g}, 10.0 \mathrm{mmol})$ and formamide (4.5 g, $100.0 \mathrm{mmol})$ were heated in an oil bath at $155-160{ }^{\circ} \mathrm{C}$ for $5 \mathrm{~h}$. The yellow residue obtained after cooling was pulverized and washed with $5 \%$ sodium bicarbonate solution, then with cold water, dried and recrystallized to give compound 2 in yield $81 \%$; m.p $232-234{ }^{\circ} \mathrm{C}(\mathrm{Aq} . \mathrm{EtOH})$; IR $\left(\mathrm{KBr}, \mathrm{cm}^{-1}\right): 2940$ (Aromatic CH stretching), $1465(\mathrm{C}=\mathrm{N}) ;{ }^{1} \mathrm{H}$ NMR $\left(\mathrm{CDCl}_{3}\right) \delta 2.4(\mathrm{~s}, 3 \mathrm{H}$ of $\left.\mathrm{CH}_{3}\right), 7.5-8.0(\mathrm{~m}, 4 \mathrm{H}$ of $\mathrm{Ar}-\mathrm{H}), 10.3(\mathrm{~s}, 1 \mathrm{H}$ of $\mathrm{NH}) ; \mathrm{MS}(\mathrm{m} / \mathrm{z}): \mathrm{M}^{+1}=347$.

\section{4-Chloro-2-(trichloromethyl) quinazoline (3)}

2-Methyl quinazolin-4(3H)-one (2) (1.6 g, $10.0 \mathrm{mmol})$, phosphorous pentachloride (10.41 g, $50 \mathrm{mmol})$ and phosphorous oxychloride $(20 \mathrm{~mL})$ were heated under reflux for $6 \mathrm{~h}$ at $115-118^{\circ} \mathrm{C}$. Excess of phosphorous oxychloride was removed by distillation under reduced pressure. The residue was extracted three times with ethyl acetate. The combined organic phase was washed with sodium bicarbonate solution (5.0\%), dried over anhydrous $\mathrm{Na}_{2} \mathrm{SO}_{4}$ and concentrated under reduced pressure. The crude product thus obtained was purified by column chromatography (60/120) using n-hexane-ethyl acetate (9:1) mixture as eluent to give compound 3 in yield 47\%; m.p 118-119 ${ }^{\circ} \mathrm{C}$ (Aq. EtOH); IR $\left(\mathrm{KBr}, \mathrm{cm}^{-1}\right): 2945$ (Aromatic CH stretching), $1455(\mathrm{C}=\mathrm{N})$; ${ }^{1} \mathrm{H}$ NMR $\left(\mathrm{CDCl}_{3}\right) \delta: 7.5-8.3(\mathrm{~m}, 4 \mathrm{H}$ of $\mathrm{Ar}-\mathrm{H}) ; \mathrm{MS}(\mathrm{m} / \mathrm{z}): \mathrm{M}^{+1}=283$.

\section{4-Substituted-2-(trichloromethyl)quinazolines $(\mathbf{4 a - j})$}

4-Chloro-2-(trichloromethyl) quinazoline $(1.4 \mathrm{~g}, 5 \mathrm{mmol})$, appropriate secondary amine $(10 \mathrm{mmol})$ were dissolve in $15 \mathrm{~mL}$ of dichloromethane and catalytic amount of KI was added. 
The mixture was refluxed for 15-18 h. After completion of reaction (TLC monitored), the solvent was evaporated and the residue was extracted $(10 \mathrm{~mL} \times 3)$ with hot petroleum ether. Combined extracts upon cooling resulted solid separation, which was recrystallized by petroleum ether to afford color solids. (Yields: 55-85\%, Table 1).

Table 1. Physical characterization data of quinazolines derivatives (4a-j)

\begin{tabular}{|c|c|c|c|c|c|c|}
\hline S.No & $\begin{array}{l}\text { Compound } \\
\text { code }\end{array}$ & $\mathrm{R}$ & $\begin{array}{c}\text { Yield } \\
\%\end{array}$ & M.P ${ }^{\circ} \mathrm{C}$ & $\begin{array}{c}\text { Mol. } \\
\text { formula }\end{array}$ & $\begin{array}{c}\text { Mol. } \\
\text { weight }\end{array}$ \\
\hline 1 & $4 a$ & & 85 & $98-100$ & $\mathrm{C}_{14} \mathrm{H}_{15} \mathrm{Cl}_{3} \mathrm{~N}_{4}$ & 346 \\
\hline 2 & $4 b$ & & 75 & $226-228$ & $\mathrm{C}_{14} \mathrm{H}_{14} \mathrm{Cl}_{3} \mathrm{~N}_{3}$ & 331 \\
\hline 3 & $4 c$ & & 65 & $88-90$ & $\mathrm{C}_{13} \mathrm{H}_{12} \mathrm{Cl}_{3} \mathrm{~N}_{3}$ & 317 \\
\hline 4 & 4d & & 70 & 102-104 & $\mathrm{C}_{13} \mathrm{H}_{12} \mathrm{Cl}_{3} \mathrm{~N}_{3} \mathrm{O}$ & 333 \\
\hline 5 & $4 e$ & & 68 & $60-62$ & $\mathrm{C}_{15} \mathrm{H}_{17} \mathrm{Cl}_{3} \mathrm{~N}_{4} \mathrm{O}$ & 376 \\
\hline 6 & $4 f$ & & 65 & $188-190$ & $\mathrm{C}_{13} \mathrm{H}_{14} \mathrm{Cl}_{3} \mathrm{~N}_{3} \mathrm{O}_{2}$ & 351 \\
\hline 7 & $4 g$ & & 68 & $80-82$ & $\mathrm{C}_{15} \mathrm{H}_{18} \mathrm{Cl}_{3} \mathrm{~N}_{3}$ & 347 \\
\hline 8 & $4 h$ & & 60 & $178-180$ & $\mathrm{C}_{12} \mathrm{H}_{7} \mathrm{Cl}_{3} \mathrm{~N}_{4}$ & 314 \\
\hline 9 & $4 i$ & & 57 & $250-252$ & $\mathrm{C}_{13} \mathrm{H}_{13} \mathrm{Cl}_{3} \mathrm{~N}_{4}$ & 314 \\
\hline 10 & $4 j$ & & 55 & $170-172$ & $\mathrm{C}_{14} \mathrm{H}_{15} \mathrm{Cl}_{3} \mathrm{~N}_{4}$ & 346 \\
\hline
\end{tabular}

4-(4-Methylpiperazin-1-yl)-2-(trichloromethyl)quinazoline (4a)

Light orange color solid, yield 85\%, m.p 98-100 ${ }^{\circ} \mathrm{C}$; IR $\left(\mathrm{KBr}, \mathrm{cm}^{-1}\right): 2943$ (Aromatic CH stretching), $1485(\mathrm{C}=\mathrm{N}) ;{ }^{1} \mathrm{H}$ NMR $\left(\mathrm{CDCl}_{3}\right) \delta 2.3\left(\mathrm{~s}, 3 \mathrm{H}\right.$ of $\mathrm{CH}_{3}$ of $\left.-\mathrm{N}-\mathbf{C H}_{3}\right), 2.5-2.6(\mathrm{t}, 4 \mathrm{H}$ of $2 \mathrm{CCH}_{2}$ of $\left.-\mathbf{C H}_{2}-\mathrm{N}\left(\mathrm{CH}_{3}\right)-\mathbf{C H}_{2}-\right)$, 3.8-3.9 (t, $4 \mathrm{H}$ of $2 \mathrm{xCH}_{2}$ of $-\mathbf{C H}_{2}-\mathrm{N}(\mathrm{Ar})-\mathbf{C H}_{2}$ ), 7.4-8.0 $(\mathrm{m}, 4 \mathrm{H}$ of $\mathrm{Ar}-\mathrm{H}) ; \mathrm{MS}(\mathrm{m} / \mathrm{z}): \mathrm{M}^{+1}=347$.

\section{4-(Piperidin-1-yl)-2-(trichloromethyl)quinazoline (4b)}

Light yellow color solid, yield 75\%, m.p 88-90 ${ }^{\circ} \mathrm{C}$; IR $\left(\mathrm{KBr}, \mathrm{cm}^{-1}\right): 2935$ (Aromatic $\mathrm{CH}$ stretching), $1475(\mathrm{C}=\mathrm{N}) ;{ }^{1} \mathrm{H}$ NMR $\left(\mathrm{CDCl}_{3}\right) \delta 1.5-1.7\left(\mathrm{~m}, 6 \mathrm{H}\right.$ of $3 \mathrm{XCH}_{2}$ of $\left.-\mathbf{C H}_{2}-\mathbf{C H}_{2}-\mathbf{C H}_{2}-\right)$, 3.7-3.8 (t, $4 \mathrm{H}$ of $2 \mathrm{xCH}_{2}$ of $\left.-\mathbf{C H}_{2}-\mathrm{N}(\mathrm{Ar})-\mathbf{C H}_{2^{-}}\right), 7.5-8.0(\mathrm{~m}, 4 \mathrm{H}$ of $\mathrm{Ar}-\mathrm{H}) ; \mathrm{MS}(\mathrm{m} / \mathrm{z}): \mathbf{M}^{+1}=332$.

4-(Pyrrolidin-1-yl)-2-(trichloromethyl)quinazoline (4c)

Light brown color solid, yield 65\%, m.p 226-228 ${ }^{\circ} \mathrm{C}$; IR $\left(\mathrm{KBr}, \mathrm{cm}^{-1}\right): 2949$ (Aromatic CH stretching), $1495(\mathrm{C}=\mathrm{N}) ;{ }^{1} \mathrm{H} \mathrm{NMR}\left(\mathrm{CDCl}_{3}\right) \delta 1.8-1.9\left(\mathrm{t}, 4 \mathrm{H}\right.$ of $2 \mathrm{xCH}_{2}$ of $\left.-\mathbf{C H}_{\mathbf{2}^{-}}-\mathbf{C H}_{\mathbf{2}^{-}}\right), 3.3-$ 3.4 (t, $4 \mathrm{H}$ of $2 \mathrm{xCH}_{2}$ of $\left.-\mathbf{C H}_{2}-\mathrm{N}-(\mathrm{Ar})-\mathbf{C H}_{2}-\right), 7.6-8.3(\mathrm{~m}, 4 \mathrm{H}$ of $\mathrm{Ar}-\mathrm{H}) ; \mathrm{MS}(\mathrm{m} / \mathrm{z}): \mathbf{M}^{+1}=318$. 


\section{4-(2-(Trichloromethyl)quinazolin-4-yl)morpholine (4d)}

Cream color solid, yield 70\%, m.p 102-104 ${ }^{\circ} \mathrm{C}$; IR $\left(\mathrm{KBr}, \mathrm{cm}^{-1}\right): 2952$ (Aromatic $\mathrm{CH}$ stretching), $1488(\mathrm{C}=\mathrm{N}) ;{ }^{1} \mathrm{H}$ NMR $\left(\mathrm{CDCl}_{3}\right) \delta 3.3-3.4\left(\mathrm{t}, 4 \mathrm{H}\right.$ of $2 \mathrm{xCH}_{2}$ of $\left.-\mathbf{C H}_{2}-\mathrm{N}-(\mathrm{Ar})-\mathbf{C H}_{2^{-}}\right)$, 3.7-3.8 (t, $4 \mathrm{H}$ of $2 \mathrm{xCH}_{2}$ of $\left.-\mathbf{C H}_{2^{-}}-\mathbf{C H}_{2^{-}}\right), 7.5-8.3(\mathrm{~m}, 4 \mathrm{H}$ of $\mathrm{Ar}-\mathrm{H}) ; \mathrm{MS}(\mathrm{m} / \mathrm{z}): \mathbf{M}^{+1}=334$.

\section{2-(4-(2-(Trichloromethyl)quinazolin-4-yl) piperazin-1-yl)ethanol (4e)}

Light yellow color solid, yield 68\%, m.p 60-62 ${ }^{\circ} \mathrm{C}$; IR $\left(\mathrm{KBr}, \mathrm{cm}^{-1}\right): 2965$ (Aromatic $\mathrm{CH}$ stretching), $1475(\mathrm{C}=\mathrm{N}) ;{ }^{1} \mathrm{H}$ NMR $\left(\mathrm{CDCl}_{3}\right) \delta 2.3-2.4\left(\mathrm{~m}, 4 \mathrm{H} 2 \mathrm{xCH}_{2}\right.$ of $\left.-\mathbf{C H}_{2}-\mathrm{N}-(\mathrm{Ar})-\mathbf{C H}_{2}-\right)$, 2.8-3.0 (t, $2 \mathrm{H}$ of $-\mathrm{N}-\mathbf{C H}_{2}-\mathrm{CH}_{2}-\mathrm{OH}$ and, 3.4-3.5 (t, $4 \mathrm{H}$ of $2 \mathrm{CCH}_{2}$ of $\left.-\mathbf{C H}_{2}-\mathrm{N}^{-}-\mathrm{CH}_{2}-\right)-\mathbf{C H}_{2}$ ), 4.2-4.3 (q, 2H of $-\mathrm{CH}_{2}$ of $\left.-\mathrm{N}-\mathrm{CH}_{2}-\mathbf{C H}_{2}-\mathrm{OH}\right), 5.2$ (s, $1 \mathrm{H}$ of $\mathrm{OH}$ of $\left.-\mathrm{CH}_{2} \mathrm{OH}\right), 7.6-8.4(\mathrm{~m}, 4 \mathrm{H}$ of $\mathrm{Ar}-\mathrm{H}) ; \mathrm{MS}(\mathrm{m} / \mathrm{z}): \mathbf{M}^{+1}=377$.

\section{2, 2'-(2-(Trichloromethyl)quinazolin-4-ylazanediyl)diethanol (4f)}

Light yellow color solid, yield 65\%, m.p 188-190 ${ }^{\circ} \mathrm{C}$; IR $\left(\mathrm{KBr}, \mathrm{cm}^{-1}\right): 2960$ (Aromatic CH stretching), $1475(\mathrm{C}=\mathrm{N}) ;{ }^{1} \mathrm{H}$ NMR $\left(\mathrm{CDCl}_{3}\right) \delta 3.6-3.7\left(\mathrm{t}, 4 \mathrm{H}\right.$ of $2 \mathrm{xCH}_{2}$ of N-(- $\mathbf{C H}_{2}-\mathrm{CH}_{2}-$ $\mathrm{OH})_{2}, 4.1-4.3\left(\mathrm{t}, 4 \mathrm{H} \text { of } 2 \mathrm{xCH}_{2} \text { of } \mathrm{N}-\mathrm{CH}_{2}-\mathbf{C H}_{2}-\mathrm{OH}\right)_{2}, 4.8-5.0$ (bs, $2 \mathrm{H}$ of $2 \times \mathrm{OH}$ ), 7.6-8.3 $(\mathrm{m}, 4 \mathrm{H}$ of $\mathrm{Ar}-\mathrm{H})$; $\mathrm{MS}(\mathrm{m} / \mathrm{z}): \mathrm{M}^{+1}=352$.

\section{$N, \mathrm{~N}$-Diethyl-2-(trichloromethyl)quinazolin-4-amine (4g)}

Light brown color solid, yield 68\%, m.p 80-82 ${ }^{\circ} \mathrm{C}$; IR $\left(\mathrm{KBr}, \mathrm{cm}^{-1}\right): 2965$ (Aromatic $\mathrm{CH}$ stretching), $1465(\mathrm{C}=\mathrm{N}) ;{ }^{1} \mathrm{H}$ NMR $\left(\mathrm{CDCl}_{3}\right) \delta 1.1-1.2\left(\mathrm{~m}, 6 \mathrm{H}\right.$ of $2 \mathrm{xCH}_{3}$ of $-\mathrm{N}-\left(\mathrm{CH}_{2}-\mathrm{CH}_{3}\right)_{2}$, 3.8-3.9 (t, $4 \mathrm{H}$ of $2 \mathrm{xCH}_{2}$ of $\left.-\mathrm{N}-\mathrm{CH}_{2}-\mathrm{CH}_{3}\right)_{2}, 7.6-8.3(\mathrm{~m}, 4 \mathrm{H}$ of $\mathrm{Ar}-\mathrm{H})$; $\mathrm{MS}(\mathrm{m} / \mathrm{z}): \mathrm{M}^{+1}=352$.

\section{4-(1H-imidazol-1-yl)-2-(trichloromethyl)quinazoline (4h)}

Light brown color solid, yield 60\%, m.p 178-180 ${ }^{\circ} \mathrm{C}$; IR $\left(\mathrm{KBr}, \mathrm{cm}^{-1}\right)$ : 2945 (Aromatic CH stretching), $1485(\mathrm{C}=\mathrm{N}){ }^{1} \mathrm{H}$ NMR $\left(\mathrm{CDCl}_{3}\right) \delta 7.1-8.0(\mathrm{~m}, 6 \mathrm{H}$ of $\mathrm{Ar}-\mathrm{H}(4 \mathrm{H}$ of quinazoline and $2 \mathrm{H}$ of Imidazole), 8.3 (s, $1 \mathrm{H}$ of $-\mathrm{CH}$ of Imidazole ring); $\mathrm{MS}(\mathrm{m} / \mathrm{z}): \mathrm{M}^{+1}=315$.

\section{4-(Piperazin-1-yl)-2-(trichloromethyl)quinazoline (4i)}

Light brown color solid, yield 57\%, m.p 250-252 ${ }^{\circ} \mathrm{C}$; IR $\left(\mathrm{KBr}, \mathrm{cm}^{-1}\right)$ : 2940 (Aromatic CH stretching), $1485(\mathrm{C}=\mathrm{N}) ;{ }^{1} \mathrm{H}$ NMR $\left(\mathrm{CDCl}_{3}\right) \delta 2.1(\mathrm{~s}, 1 \mathrm{H}$ of $\mathrm{NH}), 2.7-2.8\left(\mathrm{t}, 4 \mathrm{H}\right.$ of $2 \mathrm{xCH}_{2}$ of $\mathbf{C H}_{2}-\mathrm{NH}-\mathbf{C H}_{2^{-}}$), 3.3-3.4 (t, $4 \mathrm{H}$ of $2 \mathbf{x C H}_{2}$ of $\left.-\mathbf{C H}_{2}-\mathrm{N}(-\mathrm{Ar})-\mathbf{C H}_{2}-\right)$, 7.5-8.3 (m, $4 \mathrm{H}$ of $\left.\mathrm{Ar}-\mathrm{H}\right)$; $\operatorname{MS}(\mathrm{m} / \mathrm{z}): \mathbf{M}^{+1}=347$.

\section{4-(1,4-Diazepan-1-yl)-2-(trichloromethyl)quinazoline $\mathbf{( 4 j )}$}

Light yellow color solid, yield 55\%, m.p 170-172 ${ }^{\circ} \mathrm{C}$; IR $\left(\mathrm{KBr}, \mathrm{cm}^{-1}\right)$ : 2935 (Aromatic CH stretching), $1465(\mathrm{C}=\mathrm{N}) ;{ }^{1} \mathrm{H} \mathrm{NMR}\left(\mathrm{CDCl}_{3}\right) \delta 1.7-1.9\left(\mathrm{q}, 2 \mathrm{H}\right.$ of $-\mathrm{CH}_{2}$ of $-\mathrm{N}-\mathrm{CH}_{2}-\mathbf{C H}_{2}-\mathrm{CH}_{2}-$ NH-), 2.6-2.7 (m, $4 \mathrm{H}$ of $2 \mathrm{xCH}_{2}$ of $\left.-\mathbf{C H}_{2}-\mathrm{NH}-\mathbf{C H}_{2}\right), 3.3-3.5\left(\mathrm{~m}, 4 \mathrm{H}\right.$ of $2 \mathrm{xCH}_{2}$ of $-\mathbf{C H}_{2}-\mathrm{N}$ $\left.(-\mathrm{Ar})-\mathbf{C H}_{2}\right), 7.5-8.2(\mathrm{~m}, 4 \mathrm{H}$ of $\mathrm{Ar}-\mathrm{H}) ; \mathrm{MS}(\mathrm{m} / \mathrm{z}): \mathbf{M}^{+1}=347$.

In vitro evaluation of anti-tubercular activity

The anti-tubercular activity of the newly synthesized compounds was evaluated by Micro plate Alamar Blue assay method (MABA) ${ }^{11}$ on bacterial strain M. tuberculosis H37Rv ATCC (American Type Culture Collection), inoculums was grown on $100 \mathrm{~mL}$ of Middle brook $7 \mathrm{H} 9$ broth (Difco, Detroit Mich.) supplemented with $0.2 \%(\mathrm{v} / \mathrm{v})$ glycerol, $10 \%(\mathrm{v} / \mathrm{v})$ OADC (Oleic acid, albumin, dextrose, catalase, Difco) and $0.5 \%(\mathrm{v} / \mathrm{v})$ Tween 80 . The complete medium referred to as 7H9GC-T80. The Anti-TB susceptibility testing was performed in black, clear bottomed, 96-well microplates in order to minimize background fluorescence. Initial drug dilution was prepared in dimethyl sulfoxide and subsequent two fold dilutions were performed 
in $0.1 \mathrm{~mL}$ of $7 \mathrm{H} 12$ media in the micro plates. The $\mathrm{H}_{37} \mathrm{Rv}$ was diluted in $7 \mathrm{H} 9$ media to reach approximately $2 \times 105 \mathrm{cfu} / \mathrm{mL}$ and $0.1 \mathrm{~mL}$ was added to wells. Wells containing compounds only were used to detect auto fluorescence of the compounds and were incubated at $37^{\circ} \mathrm{C}$. At day 7 of incubation, $20 \mu \mathrm{L}$ of Alamar blue solution and $12.5 \mathrm{~mL}$ of $20 \%$ Tween 80 were added to all the wells and the plates were re-incubated at $37{ }^{\circ} \mathrm{C}$ for $24 \mathrm{~h}$. A blue color in the well was interpreted as no bacterial growth, and pink color was scored as growth. The MIC was defined as lowest drug concentration which prevented the color change from blue to pink. The pyrazinamide and streptomycin were employed as standard drugs for the comparison of antitubercular activity and the results were tabulated in the Table 2.

Table 2. In-vitro Anti-tubercular activity (MIC in $\mu \mathrm{G}$ ) of quinazoline derivatives (4a-j)

\begin{tabular}{cccccccccc}
\hline \multirow{2}{*}{ S.NO } & $\begin{array}{c}\text { Compound } \\
\text { Code }\end{array}$ & \multicolumn{8}{c}{ Concentration, $\mu \mathrm{G}$} \\
\cline { 3 - 10 } & $\mathbf{1 0 0}$ & 50 & 25 & 12.5 & 6.25 & 3.125 & 1.6 & 0.8 \\
\hline 1 & $\mathbf{4 a}$ & $\mathbf{S}$ & $\mathbf{S}$ & $\mathbf{S}$ & $\mathbf{S}$ & $\mathbf{S}$ & $\mathrm{R}$ & $\mathrm{R}$ & $\mathrm{R}$ \\
2 & $\mathbf{4 b}$ & $\mathrm{S}$ & $\mathrm{S}$ & $\mathrm{S}$ & $\mathrm{R}$ & $\mathrm{R}$ & $\mathrm{R}$ & $\mathrm{R}$ & $\mathrm{R}$ \\
3 & $\mathbf{4 c}$ & $\mathrm{S}$ & $\mathrm{S}$ & $\mathrm{R}$ & $\mathrm{R}$ & $\mathrm{R}$ & $\mathrm{R}$ & $\mathrm{R}$ & $\mathrm{R}$ \\
4 & $\mathbf{4 d}$ & $\mathrm{S}$ & $\mathrm{S}$ & $\mathrm{S}$ & $\mathrm{R}$ & $\mathrm{R}$ & $\mathrm{R}$ & $\mathrm{R}$ & $\mathrm{R}$ \\
5 & $\mathbf{4 e}$ & $\mathbf{S}$ & $\mathbf{S}$ & $\mathbf{S}$ & $\mathbf{S}$ & $\mathrm{R}$ & $\mathrm{R}$ & $\mathrm{R}$ & $\mathrm{R}$ \\
6 & $\mathbf{4 f}$ & $\mathrm{S}$ & $\mathbf{S}$ & $\mathbf{S}$ & $\mathbf{S}$ & $\mathbf{S}$ & $\mathrm{R}$ & $\mathrm{R}$ & $\mathrm{R}$ \\
7 & $\mathbf{4 g}$ & $\mathrm{S}$ & $\mathrm{S}$ & $\mathrm{S}$ & $\mathrm{R}$ & $\mathrm{R}$ & $\mathrm{R}$ & $\mathrm{R}$ & $\mathrm{R}$ \\
8 & $\mathbf{4 h}$ & $\mathrm{S}$ & $\mathbf{S}$ & $\mathbf{S}$ & $\mathbf{S}$ & $\mathrm{R}$ & $\mathrm{R}$ & $\mathrm{R}$ & $\mathrm{R}$ \\
9 & $\mathbf{4 i}$ & $\mathrm{S}$ & $\mathrm{S}$ & $\mathrm{S}$ & $\mathrm{R}$ & $\mathrm{R}$ & $\mathrm{R}$ & $\mathrm{R}$ & $\mathrm{R}$ \\
10 & $\mathbf{4 j}$ & $\mathrm{S}$ & $\mathrm{S}$ & $\mathrm{S}$ & $\mathrm{R}$ & $\mathrm{R}$ & $\mathrm{R}$ & $\mathrm{R}$ & $\mathrm{R}$ \\
11 & Pyrazinamide & $\mathrm{S}$ & $\mathrm{S}$ & $\mathrm{S}$ & $\mathrm{S}$ & $\mathrm{S}$ & $\mathrm{S}$ & $\mathrm{R}$ & $\mathrm{R}$ \\
12 & Streptomycin & $\mathrm{S}$ & $\mathrm{S}$ & $\mathrm{S}$ & $\mathrm{S}$ & $\mathrm{S}$ & $\mathrm{R}$ & $\mathrm{R}$ & $\mathrm{R}$ \\
\hline
\end{tabular}

$S$-sensitive, $R$-resistant

\section{Results and Discussion}

The synthetic strategies adopted for the preparation of targeted compound is depicted in Scheme 1. The targeted compounds (4a-j) were synthesized by reacting 4-chloro-2(trichloromethyl) quinazoline (3) with various substituted secondary amine in dichloromethane medium refluxing for $15-18 \mathrm{~h}$ under the catalysis of KI. The precursor $N$-acetylated anthranilic acid (1) was synthesized by refluxing anthranilic acid with acetic anhydride, which was further cyclized to 2-methyl quinazoline (2) by heating with formamide at $160{ }^{\circ} \mathrm{C}$. The 2-methyl quinazoline (2) was subjected for trichlorination of activated methyl group in $\alpha$-position of the $\mathrm{sp}^{2}$ nitrogen atom in quinazoline by using phosphorous pentachloride as a powerful ionic chlorinating agent and phosphorous oxychloride as a solvent. The structure of targeted compounds was established by IR, ${ }^{1} \mathrm{HNMR}$ and Mass spectral analysis, all the targeted compounds were obtained in satisfactory yields and the structures of synthesized compounds are in agreement with spectral data.

\section{In vitro anti-tubercular activity}

Ten analogs namely $\mathbf{4 a}, \mathbf{4 b}, \mathbf{4 c}, \mathbf{4 d}, \mathbf{4 e}, \mathbf{4 f}, \mathbf{4 g}, \mathbf{4 h}, \mathbf{4 i}$ and $\mathbf{4 j}$ were evaluated for in-vitro Antitubercular activity by Alamar Blue assay method (MABA) on bacterial strain M. tuberculosis H37Rv. The results are presented in Table 2 as MIC Value. The obtained data revealed that, all the tested compounds exhibited variable degree of sensitivity profiles towards bacterial strain of M. tuberculosis H37Rv. Among the tested compounds $\mathbf{4 a}$ and $\mathbf{4 f}$ 
exhibited pronounced anti-tubercular activity (MIC $6.25 \mu \mathrm{G}$ ) which is equipotent with standard employed for the study (pyrazinamide and streptomycin), while compounds $\mathbf{4 e}$ and 4h showed a remarkable anti-tubercular activity with MIC $12.5 \mu \mathrm{G}$, whereas the compounds $\mathbf{4 b}, \mathbf{4 d}, \mathbf{4 g}, \mathbf{4 i}$ and $\mathbf{4 j}$ displayed obvious anti-tubercular activity with MIC $25.0 \mu \mathrm{G}$ and compound $\mathbf{4 c}$ showed moderate anti-tubercular activity with MIC $50.0 \mu \mathrm{G}$.

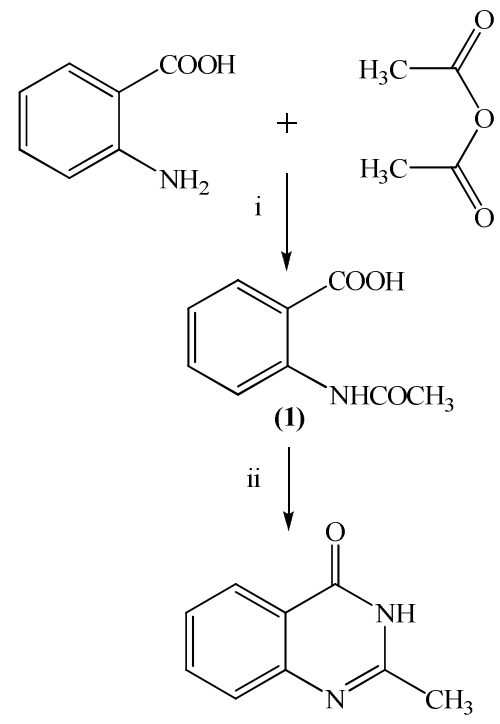

(2)<smiles>CCN(CC)c1nc(C(Cl)(Cl)Cl)nc2ccccc12</smiles>

$(4 \mathrm{~g})$<smiles>Clc1nc(C(Cl)(Cl)Cl)nc2ccccc12</smiles>

(3)

iv<smiles>[X]C1CCN(c2nc(C(Cl)(Cl)Cl)nc3ccccc23)C1</smiles>

(4a-e and $4 \mathrm{~h}-\mathrm{j}$ ) iv<smiles>OCCN(CCO)c1nc(C(Cl)(Cl)Cl)nc2ccccc12</smiles>

(4f)

\section{Scheme 1}

4a: $\mathrm{x}=-\mathrm{N}-\mathrm{CH} 3, \mathrm{n}=2 ; 4 \mathrm{~b}: \mathrm{x}=-\mathrm{CH} 2, \mathrm{n}=2 ; 4 \mathrm{c}: \mathrm{x}=-\mathrm{CH} 2, \mathrm{n}=1 ; 4 \mathrm{~d}: \mathrm{x}=2 ; 4 \mathrm{e}: \mathrm{x}=-\mathrm{N}-\mathrm{CH} 2-\mathrm{CH} 2-\mathrm{OH}, \mathrm{n}=2 ; 4 \mathrm{~h}$ : $\mathrm{x}=-\mathrm{N}, \mathrm{n}=1 ; 4 \mathrm{i}: \mathrm{x}=-\mathrm{NH}, \mathrm{n}=2: 4 \mathrm{j}: \mathrm{x}=-\mathrm{NH}, \mathrm{n}=3$.

Reaction condition and reagents: (i) reflux, $4 \mathrm{~h}, 85 \%$ : (ii) formamide, reflux, $5 \mathrm{~h} 81 \%$; (iii) POC13. PC15, reflux, 6 h, 47\%; (iv) dichloromethane; KI, reflux, 15-18 h, 55-85\%. 
In particular, compounds $\mathbf{4 a}$ and $\mathbf{4 f}$ proved to be the most active members in this study with a special effectiveness against the bacterial strain M. tuberculosis H37Rv having MIC value $6.25 \mu \mathrm{G}$. A close examination of the structure of the active compounds showed that the $N$-methyl piprazine and 4-diethanolamine counterpart at postion-4 of the 2-trilchlorometyl quinazoline skeleton is the most favorable substitution when compared with the other analogues. The differences in the MIC values may be attributed to factors such as substitution on the $4^{\text {th }}$ position of 2-tichloromethyl quinazoline nucleus, genetic and biochemical background of bacterial strain M. tuberculosis H37Rv ATCC (American Type Culture Collection).

\section{Conclusion}

The present paper describe the synthesis of 4-substituted -2- (trichloromethyl) quinazoline derivatives as possible anti-tubercular agents. The investigation of anti-tubercular activity data revealed that the compounds $4 \mathbf{a}$ and $\mathbf{4 f}$ displayed excellent activity. These lead molecules $\mathbf{4 a}$ and $\mathbf{4 f}$ could be further utilized for designing newer anti-tubercular agents.

\section{References}

1. Okunade A L, Elvin-Lewis M P F and Lewis W H Phytochemistry, 2003, 65(8), 1017-1032.

2. $\quad$ Yves L J, Bioorg Med Chem., 2007, 15(7), 2479-2513.

3. Corbrtt E L, Watt C J, Walker N, Maher D, Williams B G, Raviglione M C and Dye C, Arch Intrn Med., 2003, 163(9), 1009-1021.

4. Yew W W and Leung C C, Respirology, 2006, 11(5), 699-707.

5. Espinal A M, Tuberculosis, 2003, 83, 44-51.

6. Biava M, Porretta G C and Manetti F, Mini Rev Med Chem., 2007, 7(1), 65-78.

7. Kunes J, Bazant J, Pour M, Waisser K, Slosarek M and Janota J, Farmaco, 2000, 55, 725-729.

8. Waisser W, Bures O, Holy P, Kunes J, Oqwald R, Jiraskova L, Pour M, Klimesova V, Palat K, Kaustova J, Danse H M and Mollmann U, Pharmazie, 2003, 58(2), 83-94.

9. Waisser K, Perina M, Kunes J, Klimesova V and Kaustova J, Farmaco, 2003, 58, 1137-1149.

10. Waisser K, Matyk J, Divisova H, Husakova P, Kunes J, Klimesova V, Palat K and Kaustova J, Arch Pharm (weinheim), 2007, 340(5), 264-267.

11. Franzblau S G, Witzig R S, McLaughlin J C, Torres P, Madico G, Hernandez A, Michelle T Degnan, Mary B Cook, Virginia K Quenzer, Robert M Ferguson and Robert H, Gilma, J Clin Microbiol., 1998, 36(2), 362-366. 